\title{
EFEKTIVITAS MEDIA PERTUMBUHAN KHAMIR KOMERSIAL (Saccharomyces cerevisiae) UNTUK FERMENTASI BIOETANOL DARI ECENG GONDOK (Eichhornia crassipes)
}

\author{
Anugerah Eka Febriyanti ${ }^{1 *}$, Cut Nanda Sari ${ }^{2}$, dan Adisyahputra ${ }^{1}$ \\ ${ }^{1}$ Prodi Biologi FMIPA Universitas Negeri Jakarta (UNJ). Jl. Pemuda No. 10 Rawamangun, Jakarta Timur. \\ Indonesia. ${ }^{2}$ Lembaga Minyak dan Gas Bumi, Jakarta, Indonesia \\ *Email address: ekafebriyanti2011@gmail.com
}

\begin{abstract}
This study aims to find growth medium commercial yeast (S.cerevisiae) and determine the optimum composition of bioethanol fermentation. This research was conducted at the Laboratory of Bioprocess PPPTMGB "LEMIGAS" along May to September 2015. The method used is experiment using a completely randomized design consisting of two treatment. The first treatment is an alternative growth media utilization, namely, tofu liquid waste, coconut water and a mixture of both. The second treatment is the composition of the fermentation with sugar content of 100 $\mathrm{ml}, 150 \mathrm{ml}$ and $200 \mathrm{ml}$ with the addition of $10 \mathrm{ml}$ starter in each experiment. Data of commercial yeast cell growth (S.cerevisiae) on alternative growth media were analyzed by Anova one way. The results showed that there was an interaction of commercial yeast cell growth (S.cerevisiae) on alternative growth media. Post-hoc test showed the alternative media that consists of a mixture of tofu liquid waste and coconut water produce the highest commercial yeast cell growth at $25,8 \times 107$ with a $7.62 \mathrm{log}$ value (cells $/ \mathrm{ml}$ ). The most optimum of bioethanol produced in the fermentation process is on sugar $100 \mathrm{ml}$ by the addition of $10 \mathrm{ml}$ starter acquire as much as $45 \mathrm{ml}$ of ethanol content.
\end{abstract}

Keywords : Ethanol, Tofu Liquid Waste, Coconut Water Waste, Commercial yeast (S.cerevisiae).

\section{PENDAHULUAN}

Bioetanol merupakan salah satu energi alternatif hasil fermentasi bahan baku alami yang mengandung karbohidrat menggunakan mikroorganisme (Yitzhak, 2013). Sumber karbohidrat bukan bahan makanan yang dapat digunakan sebagai bahan baku pembuatan bioetanol adalah lignoselulosa (Singh dan Trivedi, 2013). Salah satu bahan lignoselulosa yang dapat digunakan dan melimpah jumlahnya adalah eceng gondok (Eichhornia crassipes).

Eceng gondok merupakan gulma akuatik yang memiliki kemampuan tumbuh yang sangat besar dalam waktu yang singkat (Awasthi et al., 2013). Sehingga selalu menimbulkan masalah ekosistem pada satu wilayah. Salah satu solusi yang dapat ditawarkan adalah pemanfaatan eceng gondok menjadi bahan baku bioetanol sebagai sumber energi alternatif yang ramah lingkungan (Sandip et al., 2012). Kandungan lignoselulosa pada tanaman eceng gondok terdiri dari tiga polimer yaitu selulosa, hemiselulosa, dan lignin. Menurut Katahira (2006), komponen lignoselulosa dapat dipecah menjadi monomer gula melalui proses hidrolisis menggunakan asam sulfat (H2SO4) (Erdei et al., 2010; Singh dan Trivedi, 2013).

Pada tahap selanjutnya monomer gula dapat difermentasi menjadi bioetanol menggunakan khamir komersial 
(S. cerevisiae) yang diisolasi dari ragi roti (Judoamidjojo et al., 1992). Pada skala laboratorium, pertumbuhan khamir dilakukan pada media pertumbuhan sintetis dengan biaya produksi yang tinggi seperti, YEPD (Yeast Extract Peptone Dextrose) dan YEPG (Yeast Extract Peptone Gliserol) (Purwitasari et al., 2004). Oleh karena itu, untuk kepentingan penyediaan khamir untuk fermentasi masal gula hasil pemecahan lignoselulosa eeng gondok, penelitian ini difokuskan pada pencarian formulasi medium khamir komersial yang ekonomis seperti limbah cair tahu dan limbah air kelapa. Pemilihan limbah cair tahu atas pertimbangan bahwa limbah tersebut masih mengandung bahan organik berupa protein, lemak, vitamin dan mineral sehingga berpotensi sebagai media pertumbuhan (Kasmidjo, 1990; Jenie dan Rahayu, 1993; Kuswardani dan Wijajaseputra, 1998). Sedangkan air kelapa secara potensial juga mengandung glukosa, sukrosa, fruktosa, inositol, dan sorbitol sehingga dapat digunakan sebagai media pertumbuhan (Nuraida et al., 1996; Santoso, 2003).

\section{METODE PENELITIAN}

\section{PREPARASI BIOMASSA}

Tanaman eceng gondok dicuci, kemudian dikeringkan dengan oven pada suhu $80^{\circ} \mathrm{C}$ selama 24 jam. Setelah kering, bagian tanaman dihaluskan dan diayak dengan ayakan berukuran $2 \mathrm{~mm}$ sehingga ukuran partikel lebih seragam.

\section{HIDROLISIS ASAM}

Sebanyak 30 gram serbuk kering eceng gondok dimasukan ke dalam 1liter akuades. Selanjutnya ditambahkan $40 \mathrm{ml} \mathrm{H} 2 \mathrm{SO} 4$ pekat. Bahan yang telah dicampurkan kemudian di autoclave pada suhu $121^{\circ} \mathrm{C}$ selama 15 menit. Kemudian dilakukan proses penyaringan untuk memisahkan antara residu dan filtrat biomassa.

\section{ISOLASI KHAMIR KOMERSIAL (S.CEREVISIAE) DARI FERMIPAN}

Sebanyak 1 gram ragi roti dimasukan ke dalam tabung reaksi dan ditambahkan $9 \mathrm{ml}$ akuades steril (10-1) lalu dikocok hingga menjadi homogen. Selanjutnya dilakukan pengenceran 10-2 dengan mencampurkan 1 ml homogenat dengan $9 \mathrm{ml}$ akuades steril. Hal tersebut dilakukan seterusnya hingga tingkat pengenceran mencapai 10-8. Inokulum pada pengenceran 10-1 sampai dengan pengenceran 10-8 dibiakkan pada medium PDA dengan mengambil $1 \mathrm{ml}$ larutan menggunakan pipet, kemudian disebarkan pada permukaan secara merata, lalu diinkubasi pada suhu $35^{\circ} \mathrm{C}$ selama 48 jam.

\section{PEMBUATAN KURVA PERTUMBUHAN KHAMIR KOMERSIAL (S.CEREVISIAE)}

Sebanyak satu ose working culture dipindahkan secara aseptis ke dalam $100 \mathrm{ml}$ media PDB dalam Erlenmeyer $250 \mathrm{ml}$ dan diinkubasi pada suhu $37^{\circ} \mathrm{C}$ didalam shaker pada kecepatan $100 \mathrm{rpm}$. Selanjutnya setiap dua jam sekali selama satu setengah hari, pertumbuhan sel dihitung dengan metode TPC. Metode TPC dilakukan dengan cara sebagai berikut : sebanyak $1 \mathrm{ml}$ kultur cair dipindahkan secara aseptis ke dalam $9 \mathrm{ml}$ akuades steril (10-1) lalu dikocok hingga homogen. $1 \mathrm{ml}$ dari tabung pengenceran 10-1 diambil dengan pipet ukur lalu dipindahkan ke tabung kedua dan ditambah dengan $9 \mathrm{ml}$ akuades steril (pengenceran 10-2). Hal yang sama dilakukan sampai pengenceran 10-6. Kultur cair pada tingkat pengenceran 10-1 sampai dengan pengenceran 10-6 dibiakkan pada medium PDA diambil menggunakan pipet sebanyak $1 \mathrm{ml}$, kemudian disebarkan pada permukaan secara merata dan diinkubasi pada suhu $35^{\circ} \mathrm{C}$ selama 48 jam.

PERTUMBUHAN KHAMIR KOMERSIAL PADA MEDIUM LIMBAH 
Sebanyak satu ose working culture dipindahkan secara aseptis ke dalam tiga tabung reaksi yang masing-masing berisi medium limbah cair tahu, air kelapa dan campuran kedua limbah sebanyak $100 \mathrm{ml}$. Selanjutnya ketiga tabung reaksi diinkubasi pada suhu $30^{\circ} \mathrm{C}$ selama 24 jam. Pengamatan jumlah populasi sel pada masing-masing perlakuan media alternatif dilakukan dengan metode TPC yaitu : sebanyak $1 \mathrm{ml}$ kultur cair dari masing-masing media alternatif dipindahkan secara aseptis ke dalam $9 \mathrm{ml}$ akuades steril (10-1) lalu dikocok hingga homogen. $1 \mathrm{ml}$ dari tabung pengenceran 10-1 diambil dengan pipet ukur lalu dipindahkan ke tabung kedua dan ditambah dengan $9 \mathrm{ml}$ akuades steril (pengenceran 10-2). Hal yang sama dilakukan sampai pengenceran 10-6. $1 \mathrm{ml}$ dari masing-masing pengenceran dikultur pada medium PDA dengan cara memipet $1 \mathrm{ml}$ larutan dan menyebarkan pada permukaan medium secara merata, selanjutnya didiamkan selama 48 jam sampai koloninya tumbuh.

Tabel 1. Kadar selulosa hemiselulosa dan lignin serbuk eceng gondok sebelum dan sesudah hidrolisis

\begin{tabular}{llll}
\hline \multirow{2}{*}{ Nama Kandungan } & \multicolumn{2}{l}{$\begin{array}{l}\text { Kandungan Lignoselulosa } \\
(\%)\end{array}$} & $\begin{array}{l}\text { Penurunan Kandungan Lignoselulosa } \\
(\%)\end{array}$ \\
\cline { 2 - 4 } & Awal & Akhir & \\
\hline Hemiselulosa & 29,53 & 2,13 & 27,4 \\
Selulosa & 35,54 & 13,58 & 21,96 \\
Lignin & 12,23 & 11,44 & 0,79 \\
\hline
\end{tabular}

\section{FERMENTASI BIOETANOL}

Proses fermentasi dilakukan dengan memipet masing-masing $10 \mathrm{ml}$ kultur cair medium pertumbuhan alternatif secara aseptis, selanjutnya dimasukan ke dalam medium fermentasi berupa hidolisat eceng gondok dengan variasi volume 100, 150 dan $200 \mathrm{ml}$ didalam tabung erlenmeyer berukuran $250 \mathrm{ml}$. Inkubasi dilakukan pada suhu $30^{\circ} \mathrm{C}$ selama 4 hari dan di-shaker dengan kecepatan $100 \mathrm{rpm}$. Selanjutnya dilakukan pemisahan etanol menggunakan alat destilasi sederhana. Distilasi dilakukan pada suhu $80^{\circ} \mathrm{C}$.
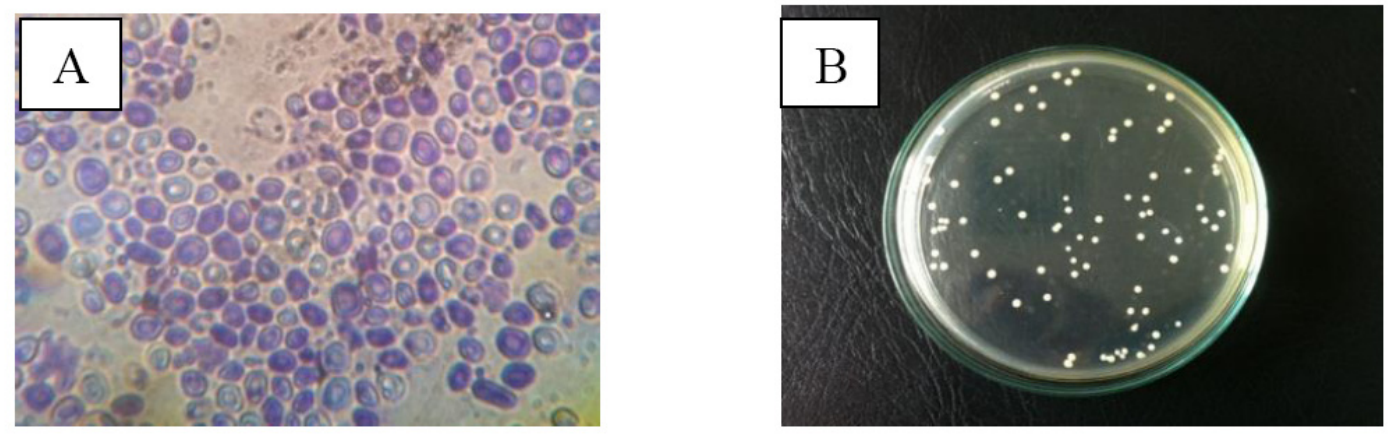

Gambar 1. A) Pengamatan sel khamir komersial (S.cerevisiae) pada mikroskop dengan perbesaran 1000x, dan (B) Pengamatan bentuk sel khamir komersil pada media PDA inkubasi 24 jam dan suhu $37^{\circ} \mathrm{C}$.

\section{HASIL DAN PEMBAHASAN}

Proses hidrolisis dengan asam (H2SO4) menyebabkan penurunan pada hemiselulosa, selulosa dan lignin. Hemiselulosa mengalami penurunan sebesar 27,4\%, sedangkan selulosa mengalami penurunan 21,96\% dan lignin hanya mengalami penurunan $0,79 \%$. Hal ini disebabkan larutan asam sulfat pada proses hidrolisis dapat memutus ikatan komponen lignoselulosa sehingga kandungannya mengalami penurunan yang ditunjukkan pada tabel dibawah 
ini.

Berdasarkan analisis pada Tabel 1, dapat diketahui bahwa yang paling mudah dihidrolisis oleh asam sulfat adalah hemiselolsa dan selulosa. Sedangkan lignin sulit untuk di hidrolisis. Penurunan kandungan hemiselulosa dan selulosa setelah proses hidrolisis menghasilkan gula reduksi sekitar 10,39\%. Kandungan gula reduksi pada hidrolisat eceng gondok selanjutnya digunakan khamir sebagai sumber karbon dalam proses fermentasi bioetanol.

Tabel 2. Jumlah pertumbuhan sel (log) khamir komersial (S.cerevisiae) pada media pertumbuhan alternatif selama 24 jam pada suhu $37^{\circ} \mathrm{C}$ dan kecepatan $100 \mathrm{rpm}$.

\begin{tabular}{lll}
\hline Media Alternatif & Rata-rata Jumlah Sel (sel/ml) & Rata-rata Jumlah Log \\
\hline Limbah Air Kelapa & $\mathbf{2 1 , 9 \times 1 0 7}$ & 7,53 \\
Limbah Cair Tahu & $\mathbf{1 2 , 9} \times 107$ & 7,33 \\
Limbah Cair Tahu \& Air Kelapa & $\mathbf{2 5 , 8 \times 1 0 7}$ & $\mathbf{7 , 6 2}$ \\
\hline
\end{tabular}

Khamir yang digunakan dalam penelitian adalah khamir komersial (S.cerevisiae) yang diisolasi dari ragi roti (gambar 1). Pada pengamatan mikroskopik sel khamir mempunyai struktur yang terdiri atas sel induk, budding sel dan sel anak. Pertumbuhan khamir komersial (S.cerevisiae) pada media PDA menunjukkan bentuk koloni bulat, permukaan licin, timbul dan memiliki warna putih kekuningan. Berdasarkan perhitungan dengan rumus Fardiaz (1992), kecepatan pertumbuhan yang dapat digunakan sebagai umur starter dalam proses fermentasi bioetanol yaitu pada jam ke -16 dengan $\mu=0,425 \mathrm{sel} / \mathrm{jam}$.

Tabel 3. Kadar gula reduksi dan bioetanol setelah fermentasi selama $\mathbf{4}$ hari pada suhu $37^{\circ} \mathrm{C}$ dan kecepatan $100 \mathrm{rpm}$

\begin{tabular}{|c|c|c|c|c|}
\hline \multirow{2}{*}{$\begin{array}{l}\text { Variasi Fer- } \\
\text { mentasi ( } 10 \mathrm{ml} \\
\text { inokulum) }\end{array}$} & \multicolumn{2}{|c|}{$\begin{array}{l}\text { Konsentrasi Gula Reduksi (mg/ } \\
\text { ml) }\end{array}$} & \multirow{2}{*}{$\begin{array}{l}\text { Presentase } \\
\text { Penurunan } \\
\text { Gula Reduksi } \\
(\%)\end{array}$} & \multirow{2}{*}{$\begin{array}{l}\text { Destilasi Bio- } \\
\text { etanol (ml) }\end{array}$} \\
\hline & Awal & Akhir & & \\
\hline $100 \mathrm{ml}$ & 10,39 & 4,95 & 52,3 & 45 \\
\hline $150 \mathrm{ml}$ & 10,39 & 4,96 & 52,2 & 23 \\
\hline $200 \mathrm{ml}$ & 10,39 & 5,49 & 47,1 & 15,5 \\
\hline
\end{tabular}

Berdasarkan pengamatan kurva pertumbuhan, khamir komersial (S.cerevisiae) yang ditumbuhkan menggunakan media standar Potato Dextrose Broth (PDB) memiliki pertumbuhan sel terbesar pada jam ke-24 yaitu 15,1x107 (sel/ml). Pertumbuhan jumlah sel tersebut digunakan sebagai standar untuk mengetahui pertumbuhan sel khamir komersial (S.cerevisiae) yang optimal pada media pertumbuhan alternatif. Dari hasil percobaan, diperoleh pertumbuhan sel yang paling tinggi terdapat pada media campuran (limbah cair tahu dan air kelapa) (Tabel 2). Hal ini dapat disebabkan media campuran (limbah cair tahu dan air kelapa) memiliki kandungan nutrisi yang diperlukan untuk pertumbuhan dan perkembangan khamir. Menurut Kristina dan Syahid (2012), kandungan air kelapa dikenal sebagai penghasil zat pengatur tumbuh alami. Selain itu, kandungan air kelapa terdiri dari karbohidrat sederhana seperti glukosa, sukrosa, fruktosa, inositol, dan sorbitol yang dapat digunakan oleh khamir sebagai sumber karbon. Selain itu, limbah cair tahu memiliki kandungan mineral, kalsium, fosfor, serta zat besi yang dapat dikonsumsi khamir (Nuraida et al., 1996). Oleh karena itu, persiapan starter yang digunakan untuk fermentasi bioetanol dapat dilakukan pada media campuran (limbah cair tahu dan air kelapa) yang dipanen pada jam ke-16, disesuaikan dengan 
pengamatan kurva laju pertumbuhan dengan media standar PDB.

Dari hasil uji gula reduksi, hidrolisat eceng gondok menghasilkan kadar gula reduksi sebesar 10,39 mg/ ml. Berdasarkan Tabel 3. dapat diketahui bahwa secara umum terjadi penurunan kadar gula reduksi selama proses fermentasi. Hal ini disebabkan karena selama proses fermentasi, terjadi konversi gula reduksi menjadi bioetanol. Pada variasi fermentasi $200 \mathrm{ml}$ terjadi penurunan kadar gula reduksi dari 10,39 mg/ml menjadi 5,49 mg/ml. Sedangkan, konversi gula reduksi yang tertinggi terjadi pada variasi fermentasi $100 \mathrm{ml}$, dengan penurunan kadar gula reduksi dari $10,39 \mathrm{mg} / \mathrm{ml}$ menjadi $4,95 \mathrm{mg} / \mathrm{ml}$. Tingginya penuruanan kadar gula reduksi secara langsung berpengaruh pada tingginya kadar etanol yang dihasilkan.

Penurunan kadar gula reduksi dapat disebabkan karena kandungan gula digunakan oleh khamir komersial (S.cerevisiae) sebagai sumber karbon (Azizah et al., 2012). Kandungan gula tersebut kemudian akan dikonversi menjadi bioetanol oleh khamir komersial (S.cerevisiae). Konversi gula reduksi yang tertinggi terjadi pada variasi fermentasi $100 \mathrm{ml}$, dengan penurunan gula reduksi dari $10,39 \mathrm{mg} / \mathrm{ml}$ menjadi 4,95 mg/ml. Data ini menunjukkan bahwa hidrolisat eceng gondok $100 \mathrm{ml}$ dengan $10 \mathrm{ml}$ starter merupakan medium yang paling sesuai bagi khamir komersial (S.cerevisiae). Hal ini berpengaruh terhadap kandungan etanol yang dihasilkan. Semakin banyak gula reduksi yang dimanfaatkan oleh khamir komersial (S.cerevisiae) maka makin tinggi pula kadar etanol yang dihasilkan yakni sebanyak $45 \mathrm{ml}$. Hal ini sesuai dengan pendapat Winarti (1996), yang menyatakan bahwa semakin banyak gula yang dapat dipecah oleh sel khamir menjadi bioetanol maka semakin tinggi pula kosentrasi bioetanol yang dihasilkan.

Sedangkan pada variasi fermentasi $200 \mathrm{ml}$, penurunan kadar gula reduksinya paling sedikit yakni dari 10,39 $\mathrm{mg} / \mathrm{ml}$ menjadi 5,49 mg/ml. Hal ini mungkin disebabkan karena pada medium ini densitas khamir yang diperlukan untuk fermentasi menjadi sangarat rendah. Akibatnya khamir harus tumbuh lagi ke densitas idealnya, sehingga konversi gula menjadi bioetanol tidak dapat dihasilkan secara maksimal. Disamping itu kandungan gula yang lebih pekat dapat mengakibatkan laju fermentasi menjadi lambat, karena kandungan gula lebih banyak digunakan untuk reproduksi sel terlebih dahulu (Agbogbo et al., 2007). Baru setelah itu, sel khamir akan mengkonversi gula menjadi bioetanol secara perlahan. Kandungan bioetanol yang dihasilkan pada hidrolisat eceng $200 \mathrm{ml}$ hanya diperoleh sebanyak 15,5 ml. Hal ini diperkirakan karena pada konsentrasi gula yang tinggi dibutuhkan inokulum yang lebih banyak untuk mengkonversi gula menjadi bioetanol (Wahyudi, 1997).

\section{KESIMPULAN}

Media pertumbuhan yang paling efektif untuk khamir komersial (S.cerevisiae) adalah campuran limbah cair tahu dan air kelapa. Selain itu, kandungan bioetanol yang tinggi terdapat pada kondisi fermentasi hidrolisat eceng gondok sebanyak $100 \mathrm{ml}$ dengan penambahan starter $10 \mathrm{ml}$.

\section{DAFTAR PUSTAKA}

Awasthi, M., Kaur J., dan Shiwali R. 2013. Bioethanol Production Through Water Hyacinth Eichhornia Crassipes Via Optimization Of The Pretreatment Conditions. Int. J. Emerging Technology and Advanced Engineering. Vol 3: 42-46. Himachal Pradesh. India.

Erdei, B., Barta Z., dan Sipos B. 2010. Etahnol Production From Mixtures Of Wheat Straw and Wheat Meal. Biotehnol. Biofuels. Vol 3: 16. 
Fardiaz, S. 1992. Mikrobiologi Pangan 1. PT. Gramedia Pustaka Utama. Jakarta

Jenie, B.S.L., dan Rahayu W.P. 1993. Penanganan Limbah Industri Pangan. Penerbit Karnisius. Yogyakarta.

Judoamidjojo, M., Darwis A. A., dan Sa’id, E. G. 1992. Teknologi Fermentasi. Edisi 1. Rajawali Press. Jakarta.

Kasmidjo. 1990. Bahan Ajaran Penanganan Limbah Pertanian, Perkebunan dan Industri Pangan. PAU (Pangan dan Gizi UGM). Yogyakarta.

Katahira S, Mizuike A., Fukuda H., dan Kondo A. 2006. Ethanol fermentation from lignocellulosic hydrolysate by a recombinant xylose-and cellooligosaccharide assimilating yeast strain. Appl. Microbiol. Biotechnol. Vol $72: 1136-43$.

Kristina, N.N. dan Syahid S. F. 2012. Pengaruh Air Kelapa Terhadap Multiplikasi Tunas In vitro, Produksi Rimpang, dan Kandungan Xanthorrhizol Temulawak Di Lapangan. J. Littri. Vol 3: 125-134.

Kumalasari, I. J. 2011. Pengaruh Variasi Suhu Inkubasi terhadap Kadar Etanol Hasil Fermentasi Kulit dan Bonggol Nanas (Ananas sativus). Skripsi. Universitas Muhammadiyah Semarang. Semarang.

Kunaepah, U. 2008. Pengaruh Lama Fermentasi dan Konsentrasi Glukosa terhadap Aktivitas Antibakteri Polifenol Total dan Mutu Kimia Kefir Susu Kacang Merah. Tesis. Universitas Diponegoro. Semarang.

Kusumaningati, M. A., Sri N., dan Anton, M. 2013. Pengaruh Konsentrasi Inokulum Bakteri Zymomonas mobilis dan Lama Fermentasi Pada Produksi Etanol dari Sampah Sayur dan Buah Pasar Wonokromo Surabaya. J. Sains Seni Pomits. Vol. 2 (2): 2337-3520. Surabaya.

Kuswardani, I. dan Wijajaseputra, A.I. 1998. Produksi Protein Sel Tunggal Phanerochaete chrysosporium pada media limbah cair tahu yang diperkaya: kajian optimasi waktu panen. Prosiding Seminar Nasional Teknologi Pangan dan Gizi. Hal: 604-613.

Nuraida, L., Sihombing H. S., dan Fardiaz S. 1996. Produksi Karotenoid Pada Limbah Cair Tahu, Air Kelapa Dan Onggok Oleh Kapang Neurospora sp. Bul. Teknol. Industri Pangan 7. Vol 1: 67-74.

Poedjiadi, A., dan Supriyanti T. 2006. Dasar-Dasar Biokimia Edisi Revisi. UI-Press. Jakarta.

Purwitasari, E., Pangastuti A., dan Setyaningsih R. 2004. Pengaruh Media Tumbuh terhadap Kadar Protein Saccharomyces cerevisiae dalam Pembuatan Protein Sel Tunggal. Bioteknol. Vol 1 (2):37-42.

Rizani, K. Z. 2000. Pengaruh Konsentrasi Gula Reduksi dan Inokulum (Saccharomyces cerevisiae) pada Proses Fermentasi Sari Kulit Nanas (Ananas comosus L. Merr) untuk Produksi Etanol. Skripsi. Universtas Brawijaya. Malang.

Sandip S. M., Sandeep M. M., dan Aiyaj A. N. 2012. Biochemical Conversion of Acid Pretreated Water Hyacinth (Eichhornia crassipes) To Alcohol Using Pichia Stipitis NCIM3497. Vol 3: 0976-2612.

Singh, D. P., dan Trivedi R. K. 2013. Acid And Alkaline Pretreatment Of Lignecellulosic Biomass To Produce Ethanol As Biofuel. J. Int. Chem. Tech. Vol 5 (2): 727-734.

Yitzhak, H. 2013. Sources for Linocellulosic Rawa Materials for the Production of Ethanol. Springer-Verlag Berlin Heidelberg. Vol 2: 1-13. 